\title{
Effect of different concentrations and ratios of ammonium, nitrate, and phosphate on growth of the blue-green alga (cyanobacterium) Microcystis aeruginosa isolated from the Nakdong River, Korea
}

\author{
Hocheol Kim, Bok Yeon Jo and Han Soon Kim* \\ School of Life Science, Kyungpook National University, Daegu 41566, Korea
}

Microcystis aeruginosa causes harmful algal blooms in the Nakdong River of Korea. We studied the effect of different concentrations and ratios of ammonium $\left(\mathrm{NH}_{4}{ }^{+}\right)$, nitrate $\left(\mathrm{NO}_{3}^{-}\right)$, and phosphate $\left(\mathrm{PO}_{4}{ }^{3-}\right)$ on growth of this species in BG-11 medium: each nutrient alone, $\mathrm{NO}_{3}{ }^{-}: \mathrm{NH}_{4}{ }^{+}$ratio, the $\mathrm{N}: \mathrm{P}$ ratio with fixed total $\mathrm{N}(\mathrm{TN})$, and the $\mathrm{N}: \mathrm{P}$ ratio with fixed total $\mathrm{P}$ (TP). The single nutrient experiments indicated that $M$. aeruginosa had the highest growth rate at $\mathrm{NH}_{4}{ }^{+}$and $\mathrm{NO}_{3}{ }^{-}$concentrations of $500 \mu \mathrm{M}$, and at a $\mathrm{PO}_{4}{ }^{3-}$ concentration of $5 \mu \mathrm{M}$. The $\mathrm{NO}_{3}{ }^{-}: \mathrm{NH}_{4}{ }^{+}$ratio experiments showed that M. aeruginosa had the highest growth rate at a ratio of $1: 1$ when TN was $100 \mu \mathrm{M}$ and $250 \mu \mathrm{M}$, and the lowest growth rate at a ratio of $1: 1$ when the TN was $500 \mu \mathrm{M}$. The N : P ratio with fixed TN experiments indicated that M. aeruginosa had the highest growth rates at $50: 1,20: 1$, and $100: 1$ ratios when the TN was 100,250 , and $500 \mu \mathrm{M}$, respectively. In contrast, the $\mathrm{N}: \mathrm{P}$ ratio with fixed TP experiments showed that M. aeruginosa had the highest growth rates at $200: 1$ ratio at all tested TP concentrations. In conclusion, our results imply that the $\mathrm{NO}_{3}{ }^{-}: \mathrm{NH}_{4}{ }^{+}$ratio and the $\mathrm{PO}_{4}{ }^{3-}$ concentration affect the early stage of growth of M. aeruginosa. In particular, our results suggest that the maximum growth of M. aeruginosa is not simply affected by the $\mathrm{NO}_{3}{ }^{-}: \mathrm{NH}_{4}{ }^{+}$ratio and the $\mathrm{N}: \mathrm{P}$ ratio, but is determined by the $\mathrm{TN}$ concentration if a certain minimum $\mathrm{PO}_{4}{ }^{3-}$ concentration is present.

Key Words: ammonium; culture study; Microcystis aeruginosa; nitrate; phosphate

\section{INTRODUCTION}

The Nakdong River is the longest river in the Republic of Korea, and it supplies drinking water for 13 million people. In recent years, summer blooms of Microcystis aeruginosa in this river have occurred more frequently and had longer durations. The Korean government has designated M. aeruginosa as a hazardous cyanobacterium that must be controlled because it produces the toxin, microcystin as well as the compounds with unpleasant taste and odor, and because its blooms have caused fish and livestock mortality (Lee et al. 2013, National Institute of
Environmental Research 2013, Ahn et al. 2015).

A high P concentration is considered the main cause of Microcystis blooms (Kim and Kang 1993, Lee et al. 1998). Schindler et al. (2008) and Schindler (2012) emphasized that $\mathrm{N}$ is unlikely to be the limiting factor for blooms because of the presence of $\mathrm{N}_{2}$-fixing cyanobacterium in water bodies. Moreover, when phosphate $\left(\mathrm{PO}_{4}{ }^{3-}\right)$ is released from the sediment during summer, Microcystis absorbs and stores it in bottom layer (Jacobson and Halmann 1982, Jung and Cho 2003a, 2003b), then moves toward the
(9) \$ This is an Open Access article distributed under the terms of the Creative Commons Attribution Non-Commercial License (http://creativecommons.org/licenses/by-nc/3.0/) which permits unrestricted non-commercial use, distribution, and reproduction in any medium, provided the original work is properly cited.
Received July 9, 2017, Accepted October 23, 2017

*Corresponding Author

E-mail: kimhsu@knu.ac.kr

Tel: +82-53-950-5344, Fax: +82-53-953-3066 


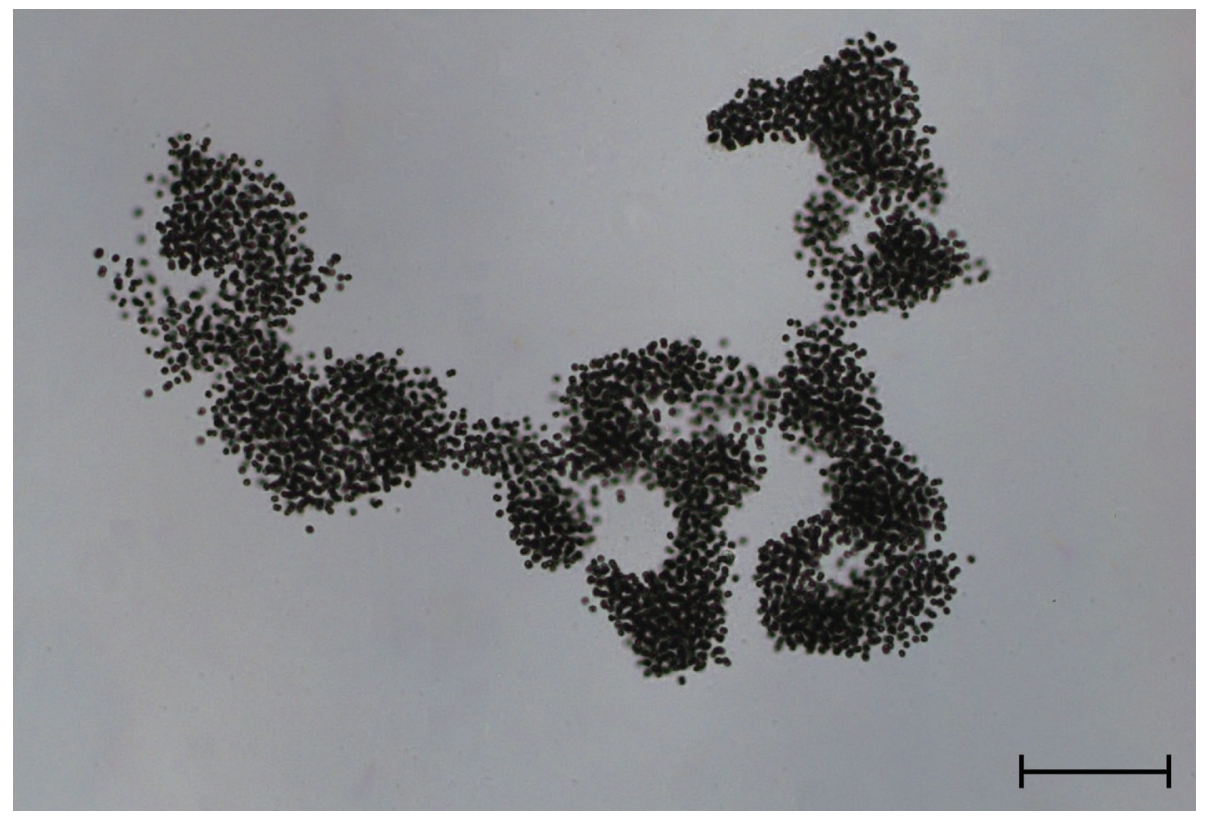

Fig. 1. Light microscopy image of a Microcystis aeruginosa colony. Scale bar represents: $100 \mu \mathrm{m}$.

high-intensity light at the surface, using its gas vacuole, and thereby generates blooms (Reynolds et al. 1981, Conley et al. 2009, Ahn et al. 2015).

Other studies have focused on the importance on $\mathrm{N}$ in cyanobacterial blooms (Conley et al. 2009, Dolman et al. 2012, Paerl et al. 2014, Hammed et al. 2016). During summer, the ammonium $\left(\mathrm{NH}_{4}^{+}\right)$concentration increases from the sediment (Jung and Cho 2003a, 2003b). Lee and Cho (2006) reported that $\mathrm{NH}_{4}{ }^{+}$affects the size of Microcystis cells. Brookes and Ganf (2001) reported that Microcystis recovers its buoyancy more quickly when the nitrate $\left(\mathrm{NO}_{3}{ }^{-}\right)$concentration is higher. Several studies reported that a low $\mathrm{NO}_{3}{ }^{-}: \mathrm{NH}_{4}{ }^{+}$ratio may promote Microcystis blooms (Liu et al. 2011, Dai et al. 2012). Thus, many studies have examined the effect of different concentrations and ratios of $\mathrm{N}$ and $\mathrm{P}$ on Microcystis proliferation and long-term growth (Park et al. 1993, Lee et al. 1998, Nalewajko and Murphy 2001, Vézie et al. 2002, Kim and Hwang 2004, Lee and Cho 2006, Baldia et al. 2007, Chen et al. 2009).

However, most these studies simply examined the effect of $\mathrm{NO}_{3}{ }^{-}$and $\mathrm{PO}_{4}{ }^{3-}$, and did not consider $\mathrm{NH}_{4}{ }^{+}$together (Lee et al. 1998, Brookes and Ganf 2001, Baldia et al. 2007). Furthermore, there are disagreements regarding the importance of the $\mathrm{N}$ : P ratio on cyanobacterial blooms (Scheffer et al. 1997, Xie et al. 2003, Kim and Hwang 2004) and about whether $\mathrm{N}$ or $\mathrm{P}$ has a more significant effect on growth of Microcystis (Conley et al. 2009, Schindler 2012, Kim et al. 2013). In particular, the P concentration in the
Nakdong River has decreased significantly since 2012 due to the efforts of the Four Rivers Restoration Project to improve water quality. Nevertheless, Microcystis blooms have become more serious in recent years and have even begun to occur during winter. Therefore, the studies of other nutrients rather than $\mathrm{P}$ have been required (Yu et al. 2014, 2015).

In this study, we aimed to identify the effect of $\mathrm{NO}_{3}$, $\mathrm{NH}_{4}{ }^{+}$, and $\mathrm{PO}_{4}{ }^{3-}$ on the growth of M. aeruginosa. We examined the effect of different concentrations of each nutrient alone, different $\mathrm{NO}_{3}{ }^{-}: \mathrm{NH}_{4}{ }^{+}$ratios, and different $\mathrm{N}$ : P ratios to clarify the effects of $\mathrm{N}$ and $\mathrm{P}$ and the role of the N : P ratio on Microcystis growth. Finally, we analyzed our results in light of recent data from the Nakdong River to suggest a strategy that may help to control Microcystis blooms.

\section{MATERIALS AND METHODS}

\section{Strain}

We used a Microcystis aeruginosa strain that was collected from the Gangjeong-Goryeong weir in Dalseonggun in Daegu, Republic of Korea on Oct 3, 2013 (Fig. 1). A colony was isolated using the capillary method (Guillard 1973). Identification was confirmed by morphological and molecular analysis, and the strain has been maintained at Kyungpook National University, Korea. 


\section{Culture conditions}

M. aeruginosa cells were cultured in BG-11 medium (Stanier et al. 1971) (Table 1), but $\mathrm{FeCl}_{3} \cdot 6 \mathrm{H}_{2} \mathrm{O}$ was substituted for ferric ammonium citrate. $\mathrm{NaNO}_{3}, \mathrm{~K}_{2} \mathrm{HPO}_{4}$, and $\mathrm{NH}_{4} \mathrm{Cl}$ were used to regulate the concentrations of $\mathrm{NO}_{3}^{-}$, $\mathrm{PO}_{4}{ }^{3-}$, and $\mathrm{NH}_{4}{ }^{+}$, respectively, and other nutrients of BG11 were controlled. Before each experiment, cells were adapted to a medium without $\mathrm{N}$ or $\mathrm{P}$ for a week. In each experiment, three 125-mL Erlenmeyer flasks with $100 \mathrm{~mL}$ of medium were autoclaved, and $M$. aeruginosa was inoculated at an initial cell density of 5,000 cells $\mathrm{mL}^{-1}$. All experiments were performed at a temperature of $30^{\circ} \mathrm{C}$, light intensity of $67 \pm 2 \mu \mathrm{mol}$ photons $\mathrm{m}^{-2} \mathrm{~s}^{-1}$ on $16: 8 \mathrm{~h}$ lightdark cycle, and at $\mathrm{pH}$ 8.0. The effects of $\mathrm{NH}_{4}{ }^{+}, \mathrm{NO}_{3}{ }^{-}$, and $\mathrm{PO}_{4}{ }^{3-}$ were tested in four sets of experiments: (1) different concentrations of each nutrient alone; (2) different $\mathrm{NO}_{3}^{-}$: $\mathrm{NH}_{4}{ }^{+}$ratios; (3) different $\mathrm{N}: \mathrm{P}$ ratios with fixed total $\mathrm{N}$ (TN) concentration and variable $\mathrm{P}$ concentration (" $\mathrm{N}: \mathrm{P}$ ratio with fixed TN"); and (4) different $\mathrm{N}$ : P ratios with fixed total $\mathrm{P}$ (TP) concentration and variable $\mathrm{N}$ concentration ("N : P ratio with fixed TP"). Furthermore, the $\mathrm{NO}_{3}{ }^{-}: \mathrm{NH}_{4}{ }^{+}$ ratio experiments and the $\mathrm{N}: \mathrm{P}$ ratio with fixed TN experiments were performed at three levels of TN $(100,250$, and $500 \mu \mathrm{M})$, and the $\mathrm{N}$ : P ratio with fixed TP experiments were performed at three levels of TP $(1,5$, and $10 \mu \mathrm{M})$. In the all experiments for $\mathrm{PO}_{4}{ }^{3-}$ concentrations and $\mathrm{N}: \mathrm{P}$ ratios, the $\mathrm{NO}_{3}{ }^{-}: \mathrm{NH}_{4}{ }^{+}$ratio was $10: 1$. Table 2 summarizes the experimental conditions.

\section{Cell counting and calculation of growth rate}

M. aeruginosa cells were counted every 3 days using a light microscope (Axio Imager A1, Zeiss, Jena, Germany) and a hemocytometer (Marienfeld-Superior, LaudaKönigshofen, Germany) at a magnification of 200×. Each experiment lasted 24 days, at which the cells were in the stationary phase or death phase. After cell counting, the number of cells per unit volume and the growth rate were calculated. The maximum growth rate $(\mu)$ was calculated as: $\mu=\ln \left(\mathrm{N}_{2} / \mathrm{N}_{1}\right) /\left(\mathrm{t}_{2}-\mathrm{t}_{1}\right)$, where $\mathrm{N}_{2}$ and $\mathrm{N}_{1}$ indicate the cell density per unit volume at times $t_{2}$ and $t_{1}$ during the exponential growth phase (Levasseur et al. 1993).

\section{Statistical analysis}

All statistical analyses were conducted using the PASW (SPSS) statistics 18 software (SPSS Inc., Chicago, IL, USA). The results were analyzed by one-way ANOVA, two-way ANOVA, and Duncan's post-hoc analysis. The results of all tests were considered significant for a p-value below 0.05 .

Table 1. Concentrations of main components and trace metal solution in modified BG-11 medium

\begin{tabular}{cccc}
\hline Main component & Concentration $\left(\mathbf{g ~ L}^{-1}\right)$ & Trace metal solution & Concentration $\left(\mathbf{g ~ L}^{-1}\right)$ \\
\hline $\mathrm{Citric}$ acid & 0.006 & $\mathrm{H}_{3} \mathrm{BO}_{3}$ & 0.00286 \\
$\mathrm{FeCl}_{3} \cdot 6 \mathrm{H}_{2} \mathrm{O}$ & 0.0029 & $\mathrm{MnCl}_{2} \cdot 4 \mathrm{H}_{2} \mathrm{O}$ & 0.00181 \\
$\mathrm{NaNO}_{3}$ & 1.5 & $\mathrm{ZnSO}_{4} \cdot 7 \mathrm{H}_{2} \mathrm{O}$ & 0.00022 \\
$\mathrm{~K}_{2} \mathrm{HPO}_{4}$ & 0.04 & $\mathrm{CuSO}_{4} \cdot 5 \mathrm{H}_{2} \mathrm{O}$ & 0.00008 \\
$\mathrm{MgSO}_{4} \cdot 7 \mathrm{H}_{2} \mathrm{O}$ & 0.075 & $\mathrm{Na}_{2} \mathrm{MoO}_{4} \cdot 2 \mathrm{H}_{2} \mathrm{O}$ & 0.00039 \\
$\mathrm{CaCl}_{2} \cdot 2 \mathrm{H}_{2} \mathrm{O}$ & 0.036 & $\mathrm{Co}\left(\mathrm{NO}_{3}\right)_{2} \cdot 6 \mathrm{H}_{2} \mathrm{O}$ & 0.00005 \\
$\mathrm{Na}_{2} \mathrm{CO}$ & - & - & - \\
$\mathrm{Na}_{2} \mathrm{EDTA}$ & 0.02 & - & - \\
\hline
\end{tabular}

Table 2. Experimental conditions used to study growth of Microcystis aeruginosa

\begin{tabular}{|c|c|c|c|}
\hline \multicolumn{2}{|c|}{ Experiment } & Concentration or ratio & Controlled factor \\
\hline \multicolumn{4}{|c|}{ Each nutrient alone } \\
\hline $\mathrm{NO}_{3}{ }^{-}$and $\mathrm{NH}_{4}{ }^{+}$ & & $1,5,10,50,100,250,500 \mu \mathrm{M}$ & $\mathrm{PO}_{4}{ }^{3-}, 230 \mu \mathrm{M}$ \\
\hline $\mathrm{PO}_{4}^{3-}$ & & $0.1,0.5,1,5,10,20,50,100 \mu \mathrm{M}$ & $\mathrm{N}, 17.65 \mathrm{mM}, \mathrm{NO}_{3}{ }^{-}: \mathrm{NH}_{4}{ }^{+}=10: 1$ \\
\hline \multirow[t]{3}{*}{$\mathrm{NO}_{3}^{-}: \mathrm{NH}_{4}^{+}$ratio } & TN $100 \mu \mathrm{M}$ & $1: 1,10: 1,50: 1,100: 1,200: 1$ & $\mathrm{PO}_{4}{ }^{3-}, 230 \mu \mathrm{M}$ \\
\hline & $\mathrm{TN} 250 \mu \mathrm{M}$ & & \\
\hline & TN $500 \mu \mathrm{M}$ & & \\
\hline \multirow[t]{3}{*}{$\mathrm{N}: \mathrm{P}$ ratio with fixed $\mathrm{TN}$} & TN $100 \mu \mathrm{M}$ & $5: 1,10: 1,20: 1,50: 1,100: 1,200: 1$ & $\mathrm{NO}_{3}{ }^{-}: \mathrm{NH}_{4}^{+}=10: 1$ \\
\hline & $\mathrm{TN} 250 \mu \mathrm{M}$ & & \\
\hline & TN $500 \mu \mathrm{M}$ & & \\
\hline \multirow[t]{3}{*}{$\mathrm{N}: \mathrm{P}$ ratio with fixed $\mathrm{TP}$} & $\mathrm{TP} 1 \mu \mathrm{M}$ & $5: 1,10: 1,20: 1,50: 1,100: 1,200: 1$ & $\mathrm{NO}_{3}{ }^{-}: \mathrm{NH}_{4}{ }^{+}=10: 1$ \\
\hline & TP $5 \mu \mathrm{M}$ & & \\
\hline & $\mathrm{TP} 10 \mu \mathrm{M}$ & & \\
\hline
\end{tabular}



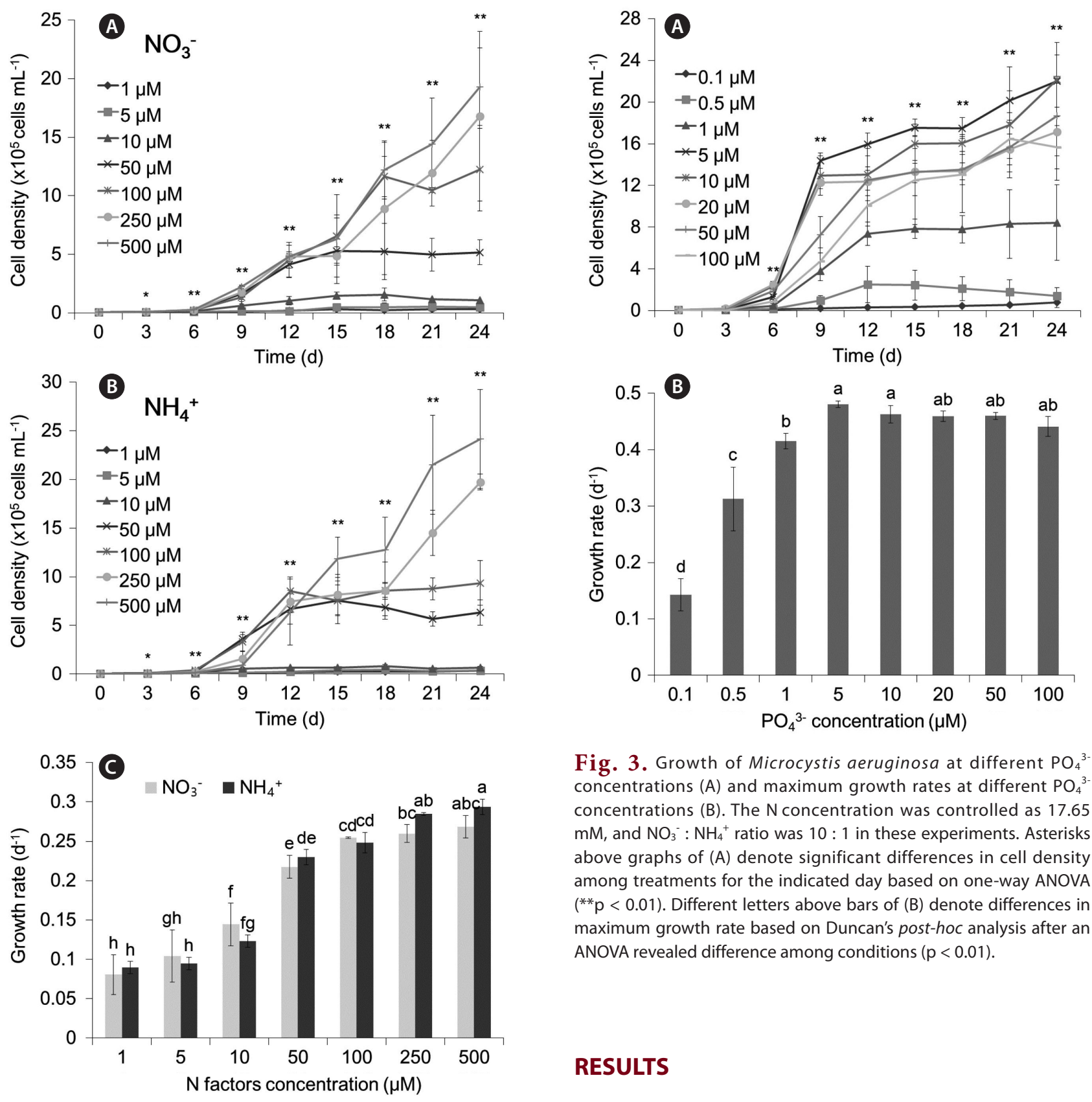

Fig. 3. Growth of Microcystis aeruginosa at different $\mathrm{PO}_{4}{ }^{3-}$ concentrations $(\mathrm{A})$ and maximum growth rates at different $\mathrm{PO}_{4}{ }^{3-}$ concentrations (B). The $\mathrm{N}$ concentration was controlled as 17.65 $\mathrm{mM}$, and $\mathrm{NO}_{3}{ }^{-}: \mathrm{NH}_{4}{ }^{+}$ratio was $10: 1$ in these experiments. Asterisks above graphs of $(A)$ denote significant differences in cell density among treatments for the indicated day based on one-way ANOVA $\left({ }^{* *} p<0.01\right)$. Different letters above bars of (B) denote differences in maximum growth rate based on Duncan's post-hoc analysis after an ANOVA revealed difference among conditions $(p<0.01)$.

\section{RESULTS}

Fig. 2. Growth of Microcystis aeruginosa at different $\mathrm{NO}_{3}$ concentrations (A) and $\mathrm{NH}_{4}{ }^{+}$concentrations (B), and maximum growth rates under all conditions (C). The $\mathrm{PO}_{4}{ }^{3-}$ concentration was controlled as $230 \mu \mathrm{M}$ in these experiments. Asterisks above graphs of $(A)$ and $(B)$ denote significant differences in cell density among treatments for the indicated day based on one-way ANOVA ( ${ }^{*} p<0.05$ and ${ }^{* *} p<0.01$ ). Different letters above bars of (C) denote differences in maximum growth rate based on Duncan's post-hoc analysis after an ANOVA revealed difference among conditions $(p<0.01)$. Here and below, error bars denote standard deviations of triplicate samples.

\section{Effect of $\mathrm{NO}_{3}{ }^{-}$and $\mathrm{NH}_{4}{ }^{+}$concentration}

The results for single condition of $\mathrm{NO}_{3}{ }^{-}$and $\mathrm{NH}_{4}{ }^{+}$are shown in Fig. 2. The maximum growth rate of M. aeruginosa occurred at $500 \mu \mathrm{M} \mathrm{NO}_{3}^{-}\left(\mu=0.268 \mathrm{~d}^{-1}\right)$ and $500 \mu \mathrm{M}$ $\mathrm{NH}_{4}{ }^{+}\left(\mu=0.294 \mathrm{~d}^{-1}\right)\left(\mathrm{p}<0.01\right.$ for each). Although $\mathrm{NO}_{3}{ }^{-}$and $\mathrm{NH}_{4}{ }^{+}$concentrations significantly affected the growth of M. aeruginosa $(\mathrm{p}<0.01)$, but the different forms of $\mathrm{N}$ had similar effects on that of this species $(\mathrm{p}=0.388)$. Moreover, the results showed that a minimum concentration of 100 $\mu \mathrm{M} \mathrm{NH}{ }_{4}^{+}$or $\mathrm{NO}_{3}{ }^{-}$was necessary to grow at least $1,000,000$ cells $\mathrm{mL}^{-1}$, a criterion for algal blooms established by the 

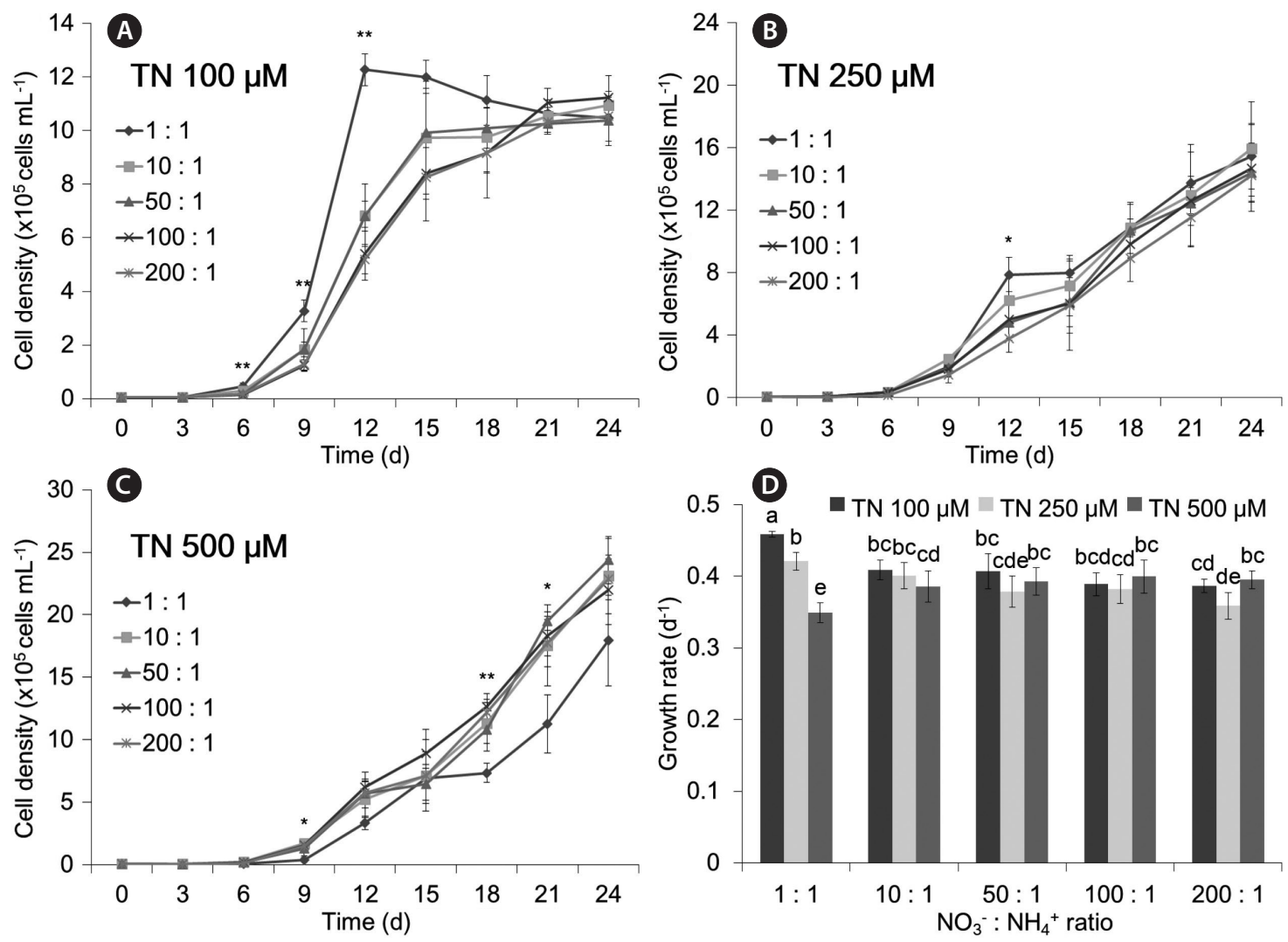

Fig. 4. Growth of Microcystis aeruginosa at different $\mathrm{NO}_{3}{ }^{-}: \mathrm{NH}_{4}{ }^{+}$ratios with a total $\mathrm{N}(\mathrm{TN})$ concentration of $100 \mu \mathrm{M}(\mathrm{A}), 250 \mu \mathrm{M}(\mathrm{B})$, and $500 \mu \mathrm{M}$ $(C)$, and maximum growth rates under all conditions (D). The $\mathrm{PO}_{4}{ }^{3-}$ concentration was controlled as $230 \mu \mathrm{M}$ in these experiments. Asterisks above graphs of (A), (B), and (C) denote significant differences in cell density among treatments for the indicated day based on one-way ANOVA ( ${ }^{*} \mathrm{p}<$ 0.05 and $\left.{ }^{* *} p<0.01\right)$. Different letters above bars of $(D)$ denote differences in maximum growth rate based on Duncan's post-hoc analysis after an ANOVA revealed difference among conditions $(p<0.01)$.

Korean algal-bloom warning system (National Institute of Environmental Research 2013).

\section{Effect of $\mathrm{PO}_{4}{ }^{3-}$ concentration}

The results for single condition of $\mathrm{PO}_{4}{ }^{3-}$ are shown in Fig. 3. The maximum growth rate of $M$. aeruginosa was at $5 \mu \mathrm{MPO}_{4}{ }^{3-}\left(\mu=0.480 \mathrm{~d}^{-1}\right)$, and growth rates at higher concentrations than $5 \mu \mathrm{M} \mathrm{PO}_{4}{ }^{3-}$ were also high but slightly lower $(\mathrm{p}<0.01)$. In addition, our results showed that a minimum of $1 \mu \mathrm{MPO}_{4}{ }^{3-}$ was necessary to grow at least $1,000,000$ cells $\mathrm{mL}^{-1}$.

\section{Effect of $\mathrm{NO}_{3}{ }^{-}: \mathrm{NH}_{4}{ }^{+}$ratio}

The results for $\mathrm{NO}_{3}{ }^{-}: \mathrm{NH}_{4}{ }^{+}$ratio of each TN level are shown in Fig. 4. At a TN concentration of $500 \mu \mathrm{M}$, the growth rate of $M$. aeruginosa was the lowest when the $\mathrm{NO}_{3}{ }^{-}: \mathrm{NH}_{4}{ }^{+}$ratio was $1: 1\left(\mu=0.349 \mathrm{~d}^{-1}\right)$ and the highest when this ratio was $100: 1\left(\mu=0.400 \mathrm{~d}^{-1}\right)$. In contrast, the other experiments showed the highest growth rates for a $\mathrm{NO}_{3}{ }^{-}: \mathrm{NH}_{4}{ }^{+}$ratio of $1: 1$ for a TN concentration of $100 \mu \mathrm{M}$ $\left(\mu=0.459 \mathrm{~d}^{-1}\right)$, and $250 \mu \mathrm{M}\left(\mu=0.421 \mathrm{~d}^{-1}\right)(\mathrm{p}<0.01$ for each comparison). Overall, the TN concentration had a significant effect on the growth of $M$. aeruginosa $(\mathrm{p}<0.05)$, but the $\mathrm{NO}_{3}{ }^{-}: \mathrm{NH}_{4}{ }^{+}$ratio had no such impact $(\mathrm{p}=0.226)$. After 24 days, the cell density was not significantly different for the diverse ratios at each TN concentration $(p=0.411$ for $100 \mu \mathrm{M} \mathrm{TN} ; \mathrm{p}=0.880$ for $250 \mu \mathrm{M} \mathrm{TN} ; \mathrm{p}=0.204$ for $500 \mu \mathrm{M}$ $\mathrm{TN})$. In addition, the cell density under each ratio became similar about $1,000,000$ cells $\mathrm{mL}^{-1}$ when the TN was 100 $\mu \mathrm{M}$, about $1,800,000$ cells $\mathrm{mL}^{-1}$ when the TN was $250 \mu \mathrm{M}$, and about 2,500,000 cells $\mathrm{mL}^{-1}$ when the TN was $500 \mu \mathrm{M}$.

\section{Effect of $\mathrm{N}$ : $\mathrm{P}$ ratio with fixed TN}

The results for $\mathrm{N}: \mathrm{P}$ ratio of each $\mathrm{TN}$ level are shown in Fig. 5. The maximum growth rate was at an $\mathrm{N}: \mathrm{P}$ ratio of 

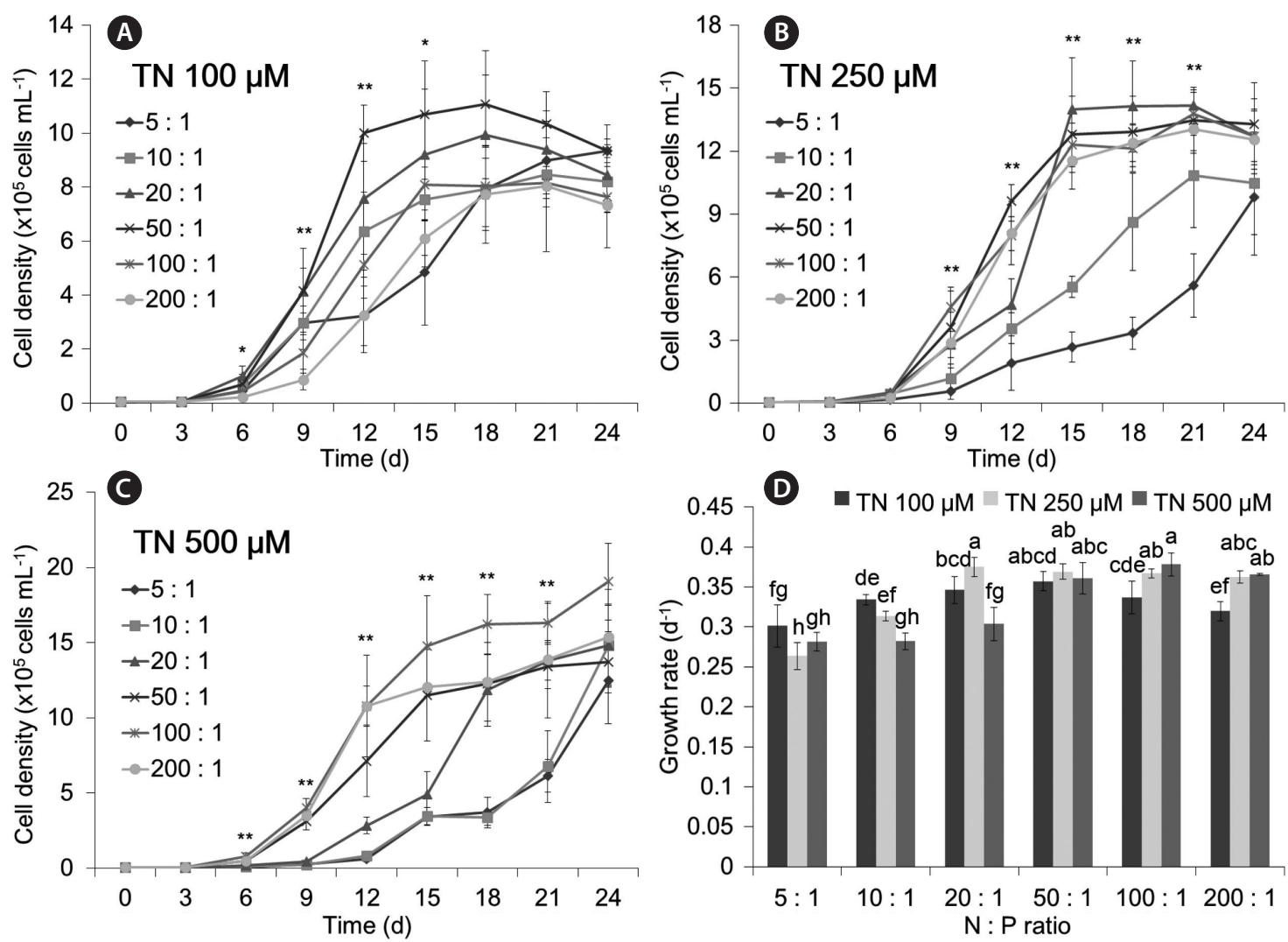

Fig. 5. Growth of Microcystis aeruginosa at different $N$ : P ratios with a fixed total $N(T N)$ concentration of $100 \mu M(A), 250 \mu M(B)$, and $500 \mu M(C)$, and maximum growth rates under all conditions (D). The $\mathrm{NO}_{3}{ }^{-}: \mathrm{NH}_{4}{ }^{+}$ratio was $10: 1$ in these experiments. Asterisks above graphs of (A), (B), and (C) denote significant differences in cell density among treatments for the indicated day based on one-way ANOVA $\left({ }^{*} p<0.05\right.$ and $\left.{ }^{* *} p<0.01\right)$. Different letters above bars of $(D)$ denote differences in maximum growth rate based on Duncan's post-hoc analysis after an ANOVA revealed difference among conditions $(p<0.01)$.

$50: 1$ when the TN was $100 \mu \mathrm{M}\left(\mu=0.357 \mathrm{~d}^{-1}\right)$, at an $\mathrm{N}: \mathrm{P}$ ratio of $20: 1$ when the TN was $250 \mu \mathrm{M}\left(\mu=0.375 \mathrm{~d}^{-1}\right)$, and at an $\mathrm{N}: \mathrm{P}$ ratio of $100: 1$ when the TN was $500 \mu \mathrm{M}(\mu=$ $\left.0.378 \mathrm{~d}^{-1}\right)(\mathrm{p}<0.01$ for each comparison). Overall, the TN concentration $(\mathrm{p}<0.05)$ and the $\mathrm{N}$ : P ratio $(\mathrm{p}<0.01)$ each had effects on the growth of M. aeruginosa. However, after 24 days, the cell density was not statistically different for the diverse $\mathrm{N}$ : P ratios $(\mathrm{p}=0.133$ for $100 \mu \mathrm{MTN}$; $\mathrm{p}=0.255$ for $250 \mu \mathrm{M} \mathrm{TN} ; \mathrm{p}=0.143$ for $500 \mu \mathrm{M} \mathrm{TN}$ ). The cell density under each ratio also became similar about 800,000 cells $\mathrm{mL}^{-1}$ when the $\mathrm{TN}$ was $100 \mu \mathrm{M}$, about $1,500,000$ cells $\mathrm{mL}^{-1}$ when the TN was $250 \mu \mathrm{M}$, and about $2,000,000$ cells $\mathrm{mL}^{-1}$ when the TN was $500 \mu \mathrm{M}$.

\section{Effect of $\mathrm{N}: \mathrm{P}$ ratio with fixed TP}

The results for $\mathrm{N}$ : P ratio of each TP level are shown in Fig. 6. At all 3 tested $P$ concentrations, the highest population growth and growth rate were at an $\mathrm{N}: \mathrm{P}$ ratio of 200
$: 1\left(\mu=0.433 \mathrm{~d}^{-1}\right.$ for $1 \mu \mathrm{M} \mathrm{TP} ; \mu=0.447 \mathrm{~d}^{-1}$ for $5 \mu \mathrm{M} \mathrm{TP} ; \mu$ $=0.475 \mathrm{~d}^{-1}$ for $10 \mu \mathrm{M}$ TP) ( $<<0.01$ for each comparison). Thus, the TP concentration $(p<0.01)$ and the N:P ratio $(p$ $<0.01$ ) significantly affected the growth of M. aeruginosa.

\section{DISCUSSION}

Our experiments indicated that the growth of M. aeruginosa increased as the $\mathrm{NO}_{3}{ }^{-}$and $\mathrm{NH}_{4}{ }^{+}$concentration increased, in agreement previous studies (Vézie et al. 2002, Lee and Cho 2006, Chen et al. 2009). Rücker and Giani (2004) reported that $\mathrm{NH}_{4}{ }^{+}$had a greater effect than $\mathrm{NO}_{3}{ }^{-}$ on the early growth of Microcystis, and that the growth rate was greater for $\mathrm{NO}_{3}^{-}$than $\mathrm{NH}_{4}{ }^{+}$. Our results also showed that $\mathrm{NH}_{4}{ }^{+}$promoted slightly faster cell growth initially, but the difference of $\mathrm{NO}_{3}^{-}$and $\mathrm{NH}_{4}{ }^{+}$did not differently affected the growth of M. aeruginosa.

The results of our experiments on the effect of the $\mathrm{PO}_{4}{ }^{3-}$ 

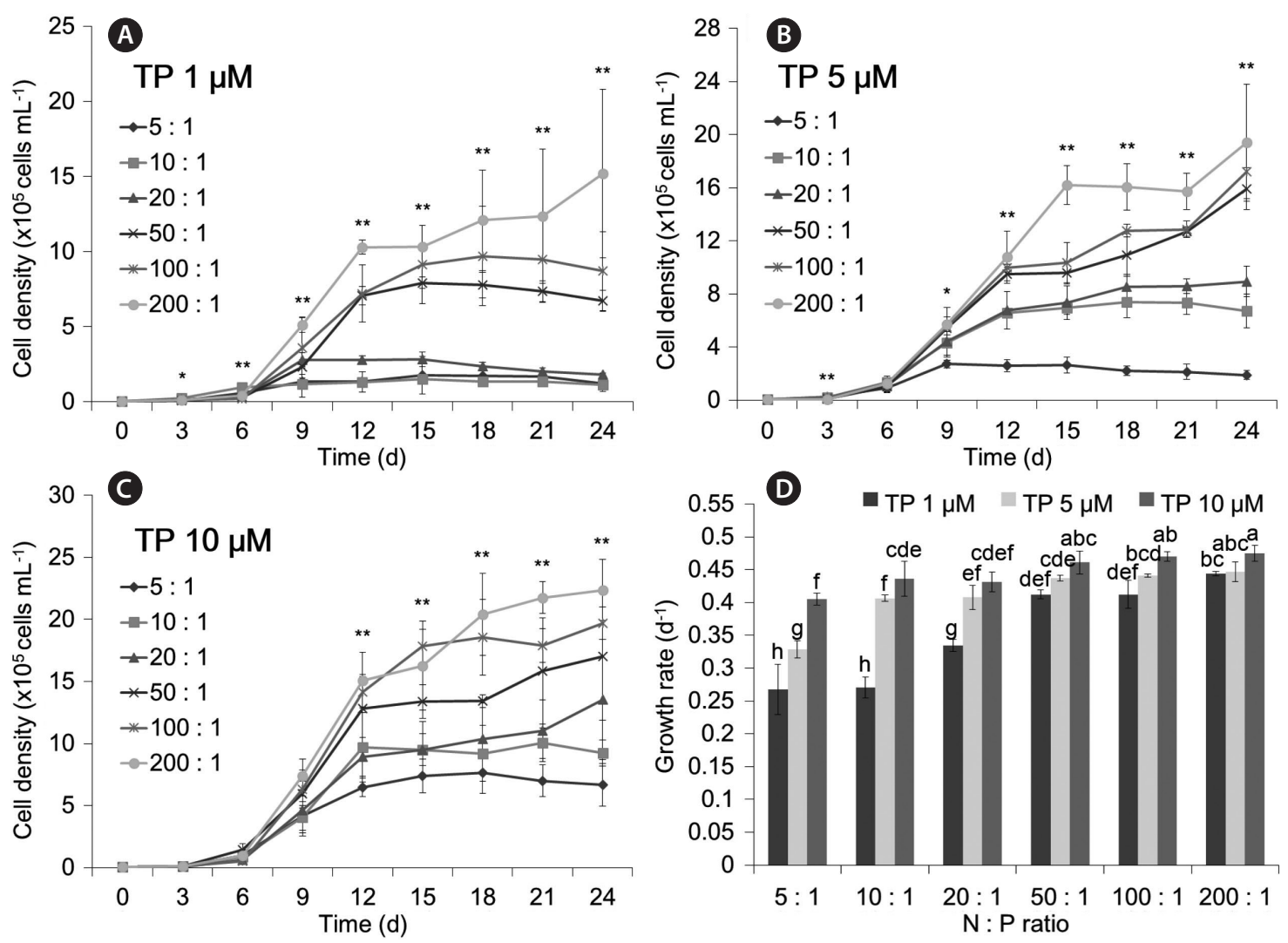

Fig. 6. Growth of Microcystis aeruginosa at different $N$ : $P$ ratios with a fixed total $P(T P)$ concentration of $1 \mu M(A), 5 \mu M(B)$, and $10 \mu M(C)$, and maximum growth rates under all conditions (D). The $\mathrm{NO}_{3}{ }^{-}: \mathrm{NH}_{4}{ }^{+}$ratio was $10: 1$ in these experiments. Asterisks above graphs of (A), (B), and (C) denote significant differences in cell density among treatments for the indicated day based on one-way ANOVA $\left({ }^{*} p<0.05\right.$ and $\left.{ }^{* *} p<0.01\right)$. Different letters above bars of $(D)$ denote differences in maximum growth rate based on Duncan's post-hoc analysis after an ANOVA revealed difference among conditions $(p<0.01)$.

concentration are in agreement with previous studies (Park et al. 1993, Lee et al. 1998), which reported that a minimum of $0.05 \mathrm{mg} \mathrm{L}^{-1}\left(1.5 \mu \mathrm{M} \mathrm{PO}_{4}{ }^{-3}\right)$ is necessary for $M$. aeruginosa growth, and 0.3-0.8 $\mathrm{mg} \mathrm{L}^{-1}\left(10-30 \mu \mathrm{M} \mathrm{PO}_{4}{ }^{3-}\right)$ is needed for a high growth rate. Baldia et al. (2007) reported that the growth rate of $M$. aeruginosa increased with $\mathrm{N}$ concentrations up to of $620 \mu \mathrm{M}\left(8.7 \mathrm{mg} \mathrm{L}^{-1}\right)$ and with $\mathrm{P}$ concentrations up to $7 \mu \mathrm{M}\left(0.22 \mathrm{mg} \mathrm{L}^{-1}\right)$. Our results also indicated that maximum growth of $M$. aeruginosa occurred at a relatively high $\mathrm{N}$ concentration, but at a relatively low $\mathrm{P}$ concentration.

When algae absorb $\mathrm{NH}_{4}^{+}$, they immediately incorporate it into amino acids; however, algae can only use $\mathrm{NO}_{3}{ }^{-}$ after enzymatic reduction to $\mathrm{NO}_{2}{ }^{-}$and $\mathrm{NH}_{4}{ }^{+}$, and these enzymatic reactions require cellular energy and thereby affect cell growth (Flynn et al. 1997, Flores et al. 2005). Therefore, algae that use $\mathrm{NH}_{4}{ }^{+}$before $\mathrm{NO}_{3}{ }^{-}$(Takamura et al. 1987, Liu et al. 2011) may experience inhibition of $\mathrm{NO}_{3}{ }^{-}$uptake (Dortch 1990, Dugdale et al. 2007). Similarly, our results showed that M. aeruginosa had a lower growth rate at a TN concentration of $500 \mu \mathrm{M}$, indicating that decreased $\mathrm{NO}_{3}{ }^{-}$absorption in the presence of $\mathrm{NH}_{4}{ }^{+}$seemed to hinder the growth of M. aeruginosa. However, Dortch (1990) reported that inhibition of $\mathrm{NO}_{3}{ }^{-}$uptake by $\mathrm{NH}_{4}{ }^{+}$ and the preference for $\mathrm{NH}_{4}{ }^{+}$uptake vary according to environmental conditions and species. We observed a similar effect for a $\mathrm{NH}_{4}{ }^{+}$concentration below $250 \mu \mathrm{M}$, suggesting that $\mathrm{NH}_{4}{ }^{+}$might inhibit $\mathrm{NO}_{3}{ }^{-}$uptake at concentrations above $250 \mu \mathrm{M}$. However, this effect only occurred during the initial growth phase, and cell densities at 24 days were similar for different TN concentrations. Therefore, our results suggest that the TN concentration has a significant role in the growth of M. aeruginosa than the form of $\mathrm{N}$.

We performed two sets of experiments to determine the effect of the $\mathrm{N}: \mathrm{P}$ ratio on growth of $M$. aeruginosa. The first set of experiments used different $\mathrm{N}$ : $\mathrm{P}$ ratios with fixed TN, and indicated that the highest growth rate was at an N : P ratio of $20: 1$ when the TN was $250 \mu \mathrm{M}$, similar 


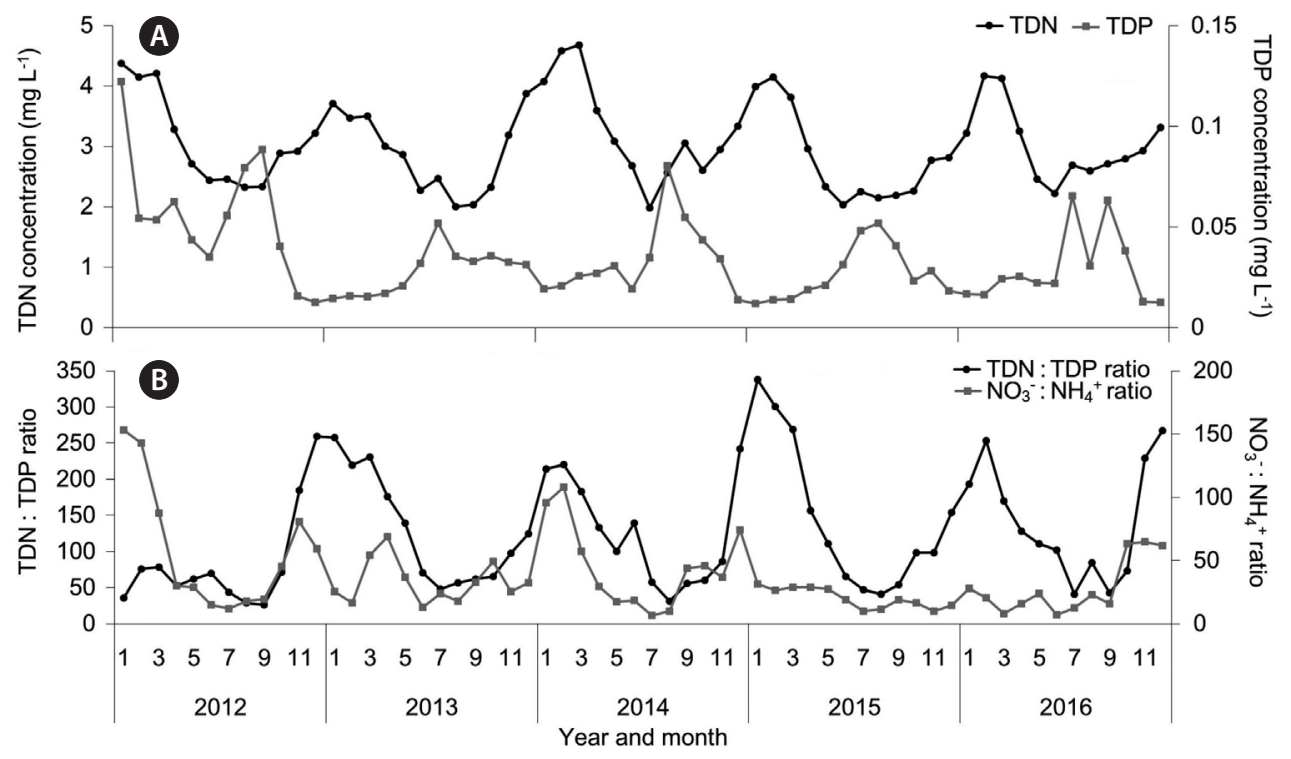

Fig. 7. Average nutrient levels in 5 sites (Changnyeong-Haman Weir, Dalseong Weir, Dodongseowon, Gangjeong-Goryeong Weir, and Hapcheon-Changnyeong Weir) of the Nakdong River (Korea) over the past 5 years. Total dissolved nitrogen (TDN) and total dissolved phosphorus (TDP) (A), and the TDN : TDP ratio and the $\mathrm{NO}_{3}{ }^{-}: \mathrm{NH}_{4}{ }^{+}$ratio (B). Data are from the Water information system (Water Information System, National Institute of Environmental Research, Korea 2016).

to the results of Kim and Hwang (2004) and Lee and Cho (2006), and the highest growth rate was at an $\mathrm{N}$ : P ratio of $100: 1$ when the TN was $500 \mu \mathrm{M}$, similar to the results of Nalewajko and Murphy (2001). However, the highest population growth rate was at an $\mathrm{N}: \mathrm{P}$ ratio of $50: 1$ when the TN was $100 \mu \mathrm{M}$, in contrast to the results of previous studies (Nalewajko and Murphy 2001, Kim and Hwang 2004, Lee and Cho 2006). Although our results were different from these previous results, their P concentrations were in the range of 2 to $12.5 \mu \mathrm{M}$, and the results are similar to the results of our experiments in which $\mathrm{PO}_{4}{ }^{3-}$ alone was varied (Fig. 3). Therefore, it seems that the $\mathrm{PO}_{4}{ }^{3-}$ concentration affects the growth of $M$. aeruginosa rather than the $\mathrm{N}$ : P ratio. However, this effect was limited to the initial growth phase and each cell density became similar for different $\mathrm{TN}$ concentrations after 24 days.

Our second set of $\mathrm{N}: \mathrm{P}$ ratio experiments used different $\mathrm{N}$ : $\mathrm{P}$ ratios with fixed $\mathrm{TP}$, and showed that the highest growth rates occurred at the $\mathrm{N}: \mathrm{P}$ ratio of $200: 1$ in all case. Kim et al. (2013) reported that there was no significant relationship between growth of $M$. aeruginosa and N : P ratio. Likewise, our results suggested that the $\mathrm{N}$ : P ratio itself did not determine the growth of $M$. aeruginosa in that different results were obtained in the two sets of experiments. In addition, some studies reported that differences in the growth of Microcystis at different $\mathrm{N}: \mathrm{P}$ ratios are due to difference in the TP concentration (Scheffer et al. 1997, Kim and Hwang 2004). However, our results suggest that increasing the $\mathrm{PO}_{4}{ }^{3-}$ concentration above $1 \mu \mathrm{M}$ had no clear effect on growth of M. aeruginosa, and only the TN concentration affected cell growth when a minimum $\mathrm{PO}_{4}{ }^{3-}$ concentration was present. In other words, it seems that the absolute amount of $\mathrm{N}$ and $\mathrm{P}$, rather than the $\mathrm{N}$ : $\mathrm{P}$ ratio, affects the growth of $M$. aeruginosa, and the $\mathrm{N}$ concentration is more critical than the $\mathrm{P}$ concentration.

Unlike other cyanobacterium, Microcystis cannot fix atmospheric $\mathrm{N}_{2}$ and relies on $\mathrm{N}$ in the water. However, this species can store extra P within its cells (Reynolds et al. 1981, Xie et al. 2003, Kim and Hwang 2004). Moreover, P-limited conditions have a less effect on small size organisms, such as Microcystis, than larger organisms because of the advantage of diffusion through an aqueous boundary layer into cell (Chisholm 1992, Lin et al. 2016). Choi and Kim (2000) also reported that Microcystis can produce organophosphate-degrading enzymes, therefore, it can use other forms of $\mathrm{P}$. As a consequence, the $\mathrm{P}$ concentration seems less important than the $\mathrm{N}$ concentration for promotion of the higher growth of Microcystis.

Most of the $\mathrm{N}$ and $\mathrm{P}$ in the Nakdong River are in the forms of $\mathrm{NH}_{4}{ }^{+}, \mathrm{NO}_{3}$, and $\mathrm{PO}_{4}{ }^{3-}$. Moreover, over the past 5 years, this river has had an average the total dissolved $\mathrm{N}$ about $215 \mu \mathrm{M}\left(3.02 \mathrm{mg} \mathrm{L}^{-1}\right)$, and an average total dissolved P of about $1.1 \mu \mathrm{M}\left(0.035 \mathrm{mg} \mathrm{L}^{-1}\right)$ (Water Information System, National Institute of Environmental Research, Korea 
2016). Owing to the efforts of the Four Rivers Restoration Project, the P concentration has remained at about $0.4 \mu \mathrm{M}$ (0.012 $\left.\mathrm{mg} \mathrm{L}^{-1}\right)$ in winter, spring, and late fall. However, the P concentration has increased to about $1.5 \mu \mathrm{M}(0.048 \mathrm{mg}$ $\mathrm{L}^{-1}$ ) every summer and early fall, when most Microcystis blooms have occurred. Moreover, the amount of N, which has a greater effect on growth of Microcystis as shown in our results, has remained at $142 \mu \mathrm{M}\left(1.98 \mathrm{mg} \mathrm{L}^{-1}\right)$ or more in every season (Fig. 7A). Therefore, the concentrations of $\mathrm{N}$ and $\mathrm{P}$ in the Nakdong River are likely to be sufficient to support summer blooms of Microcystis. Furthermore, the Nakdong River has had trends of gradual decrease in the $\mathrm{N}$ : P ratio and the $\mathrm{NO}_{3}{ }^{-}: \mathrm{NH}_{4}{ }^{+}$ratio from winter to summer of each year (Fig. 7B). However, as shown in our results, the change of $\mathrm{N}$ : $\mathrm{P}$ ratio in this river might not play a vital role in Microcystis blooms. Instead, the change of $\mathrm{N}$ :P ratio may be just a result from the that of the $\mathrm{P}$ concentration and the $\mathrm{N}$ concentration. In addition, the change of the $\mathrm{NO}_{3}{ }^{-}: \mathrm{NH}_{4}{ }^{+}$ratio and the increased level of $\mathrm{NH}_{4}{ }^{+}$in summer may favor the initial growth of Microcystis and contribute to explosive its blooms.

In conclusion, we suggest that the $\mathrm{PO}_{4}{ }^{3-}$ concentration in the Nakdong River should be reduced to below $1 \mu \mathrm{M}$ during summer and early autumn to prevent the formation of Microcystis blooms. Alternatively, the N concentration should be regulated to reduce the growth of Microcystis while maintaining the P concentration at its current level. However, the physiology of Microcystis is incompletely understood, and the $\mathrm{N}$ and $\mathrm{P}$ cycles are complicated in Nakdong River than in controlled laboratory experiments. Therefore, further studies are required to figure out physiological characteristics of Microcystis, to identify exact cause of the change of $\mathrm{NH}_{4}{ }^{+}, \mathrm{NO}_{3}{ }^{-}$and $\mathrm{PO}_{4}{ }^{3}$, and to develop effective strategies for control of $\mathrm{Mi}$ crocystis blooms.

\section{ACKNOWLEDGEMENTS}

This research was supported by Kyungpook National University Bokhyeon Research Fund, 2015.

\section{REFERENCES}

Ahn, C. -Y., Lee, C. S., Choi, J. W., Lee, S. \& Oh, H. -M. 2015. Global occurrence of harmful cyanobacterial blooms and N, P-limitation strategy for bloom control. Korean J. Environ. Biol. 33:1-6.

Baldia, S. F., Evangelista, A. D., Aralar, E. V. \& Santiago, A. E.
2007. Nitrogen and phosphorus utilization in the cyanobacterium Microcystis aeruginosa isolated from Laguna de Bay, Philippines. J. Appl. Phycol. 19:607-613.

Brookes, J. D. \& Ganf, G. G. 2001. Variations in the buoyancy response of Microcystis aeruginosa to nitrogen, phosphorus and light. J. Plankton Res. 23:1399-1411.

Chen, W., Zhang, Q. \& Dai, S. 2009. Effects of nitrate on intracellular nitrate and growth of Microcystis aeruginosa. J. Appl. Phycol. 21:701-706.

Chisholm, S. W. 1992. Phytoplankton size. In Falkowski, P. G. \& Woodhead, A. D. (Eds.) Primary Productivity and Biogeochemical Cycles in the Sea. Springer, New York, pp. 213-237.

Choi, K. S. \& Kim, B. C. 2000. A study on the kinetic parameters of alkaline phosphatase by algae. Korean J. Limnol. 33:380-386.

Conley, D. J., Paerl, H. W., Howarth, R. W., Boesch, D. F., Seitzinger, S. P., Havens, K. E., Lancelot, C. \& Likens, G. E. 2009. Controlling eutrophication: nitrogen and phosphorus. Science 323:1014-1015.

Dai, G. -Z., Shang, J. -L. \& Qiu, B. -S. 2012. Ammonia may play an important role in the succession of cyanobacterial bloom and the distribution of common algal species in shallow freshwater lakes. Glob. Chang. Biol. 18:15711581.

Dolman, A. M., Rücker, J., Pick, F. R., Fastner, J., Rohrlack, T., Mischke, U. \& Wiedner, C. 2012. Cyanobacteria and cyanotoxins: the influence of nitrogen versus phosphorus. PLoS ONE 7:e38757.

Dortch, Q. 1990. The interaction between ammonium and nitrate uptake in phytoplankton. Mar. Ecol. Prog. Ser. 61:183-201.

Dugdale, R. C., Wilkerson, F. P., Hogue, V. E. \& Marchi, A. 2007. The role of ammonium and nitrate in spring bloom development in San Francisco Bay. Estuar. Coast. Shelf Sci. 73:17-29.

Flores, E., Frías, J. E., Rubio, L. M. \& Herrero, A. 2005. Photosynthetic nitrate assimilation in cyanobacteria. Photosynth. Res. 83:117-133.

Flynn, K. J., Fasham, M. J. R. \& Hipkin, C. R. 1997. Modelling the interactions between ammonium and nitrate uptake in marine phytoplankton. Philos. Trans. R. Soc. Lond. B Biol. Sci. 352:1625-1645.

Guillard, R. R. L. 1973. Methods for microflagellates and nanoplankton. In Stein, J. R. (Ed.) Handbook of Phycological Methods: Culture Methods and Growth Measurements. Cambridge University Press, New York, pp. 66-85.

Hammed, A. M., Prajapati, S. K., Simsek, S. \& Simsek, H. 2016. Growth regime and environmental remediation of microalgae. Algae 31:189-204. 
Jacobson, L. \& Halmann, M. 1982. Polyphosphate metabolism in the blue-green alga, Microcystis aeruginosa. J. Plankton Res. 4:481-488.

Jung, H. -Y. \& Cho, K. -J. 2003a. Environmental conditions of sediment and bottom waters near sediment in the downstream of the Nagdong River. Korean J. Limnol. 36:311-321.

Jung, H. -Y \& Cho, K. -J. 2003b. SOD and inorganic nutrient fluxes from sediment in the downstream of the Nagdong River. Korean J. Limnol. 36:322-335.

Kim, E. H. \& Kang, S. K. 1993. The effect of heavy metal ions on the growth of Microcystis aeruginosa. J. Korean Soc. Water Qual. 9:193-200.

Kim, H. -S. \& Hwang, S. -J. 2004. Effects of nutrients and N/P ratio stoichiometry on phytoplankton growth in an eutrophic reservoir. Korean J. Limnol. 37:36-46.

Kim, J. -E., Park, J. -W., Jo, K. -A. \& Kim, S. -K. 2013. Variances of environmental factors during water bloom by Microcystis aeruginosa (Kützing) Kützing in Ilwol Reservoir, Suwon. Korean J. Ecol. Environ. 46:265-275.

Lee, C. S., Ahn, C. -Y., La, H. -J., Lee, S. \& Oh, H. -M. 2013. Technical and strategic approach for the control of cyanobacterial bloom in fresh waters. Korean J. Environ. Biol. 31:233-242.

Lee, O. H. \& Cho, K. J. 2006. Nitrogen and phosphorus uptake and growth kinetics of Microcystis aeruginosa cultured under chemostats. Korean J. Limnol. 39:119-130.

Lee, T. -G., Park, S. -W., Yu, T. -S. \& Kim, J. 1998. The growth and coagulation characteristics of Microcystis aeruginosa during water treatment processes. J. Korea Technol. Soc. Water Waste Water Treat. 6:33-42.

Levasseur, M., Thompson, P. A. \& Harrison, P. J. 1993. Physiological acclimation of marine phytoplankton to different nitrogen sources. J. Phycol. 29:587-595.

Lin, S., Litaker, R. W. \& Sunda, W. G. 2016. Phosphorus physiological ecology and molecular mechanisms in marine phytoplankton. J. Phycol. 52:10-36.

Liu, X., Lu, X. \& Chen, Y. 2011. The effects of temperature and nutrient ratios on Microcystis bloom in Lake Taihu, China: an 11-year investigation. Harmful Algae 10:337-343.

Nalewajko, C. \& Murphy, T. P. 2001. Effects of temperature, and availability of nitrogen and phosphorus on the abundance of Anabaena and Microcystis in Lake Biwa, Japan: an experimental approach. Limnology 2:45-48.

National Institute of Environmental Research (NIER). 2013. Research on implementing the harmful algal bloom alert system for weir in the Nakdong River watershed. NIER, Incheon, $33 \mathrm{pp}$.

Paerl, H. W., Gardner, W. S., McCarthy, M. J., Peierls, B. L. \& Wilhelm, S. W. 2014. Algal blooms: noteworthy nitrogen.
Science 346:175.

Park, H. -K., Cheon, S. U. \& Ryu, J. K. 1993. Growth characteristics of bloom-forming blue-green algae. Korean J. Phycol. 8:47-54.

Reynolds, C. S., Jaworski, G. H. M., Cmiech, H. A. \& Leedale, G. F. 1981. On the annual cycle of the blue-green alga $M i$ crocystis aeruginosa Kütz. Emend. Elenkin. Philos. Trans. R. Soc. Lond. B Biol. Sci. 293:419-476.

Rückert, G. V. \& Giani, A. 2004. Effect of nitrate and ammonium on the growth and protein concentration of Microcystis viridis Lemmermann (Cyanobacteria). Rev. Bras. Bot. 27:325-331.

Scheffer, M., Rinaldi, S., Gragnani, A., Mur, L. R. \& van Nes, E. H. 1997. On the dominance of filamentous cyanobacteria in shallow, turbid lakes. Ecology 78:272-282.

Schindler, D. W. 2012. The dilemma of controlling cultural eutrophication of lakes. Proc. Biol. Sci. 279:4322-4333.

Schindler, D. W., Hecky, R. E., Findlay, D. L., Stainton, M. P., Parker, B. R., Paterson, M. J., Beaty, K. G., Lyng, M. \& Kasian, S. E. M. 2008. Eutrophication of lakes cannot be controlled by reducing nitrogen input: results of a 37year whole-ecosystem experiment. Proc. Natl. Acad. Sci. U. S. A. 105:11254-11258.

Stanier, R. Y., Kunisawa, R., Mandel, M. \& Cohen-Bazire, G. 1971. Purification and properties of unicellular bluegreen algae (Order Chroococcales). Bacteriol. Rev. 35:171-205.

Takamura, N., Iwakuma, T. \& Yasuno, M. 1987. Uptake of ${ }^{13} \mathrm{C}$ and ${ }^{15} \mathrm{~N}$ (ammonium, nitrate and urea) by Microcystis in Lake Kasumigaura. J. Plankton Res. 9:151-165.

Vézie, C., Rapala, J., Vaitomaa, J., Seitsonen, J. \& Sivonen, K. 2002. Effect of nitrogen and phosphorus on growth of toxic and nontoxic Microcystis strains and on intracellular microcystin concentrations. Microb. Ecol. 43:443454.

Water Information System, National Institute of Environmental Research, Korea. 2016. Available from: http:// water.nier.go.kr. Accessed Oct 30, 2017.

Xie, L., Xie, P., Li, S., Tang, H. \& Liu, H. 2003. The low TN:TP ratio, a cause or a result of Microcystis bloom? Water Res. 37:2073-2080.

Yu, J. J., Lee, H. J., Lee, K. -L., Lee, I. J., Jung, G. Y. \& Chen, S. U. 2014. Effects of environmental factors on algal communities in the Nakdong River. J. Korean Soc. Water Environ. 30:539-548.

Yu, J. J., Lee, K. L., Lee, H. J., Hwang, J. W., Lyu, H. S., Shin, L. Y., Park, A. R. \& Chen, S. U. 2015. Relations of nutrient concentrations on the seasonality of algal community in the Nakdong River, Korea. J. Korean Soc. Water Environ. 31:110-119. 